\title{
Antiplasmodial activity of Vernonia cinerea Less (Asteraceae), a plant used in traditional medicine in Burkina Faso to treat malaria
}

\author{
Aboubakar Soma ${ }^{1,2 *}$, Souleymane Sanon ${ }^{1}$, Adama Gansané ${ }^{1}$, Lamoussa Paul Ouattara ${ }^{1}$, \\ Noufou Ouédraogo ${ }^{2}$, Jean-Baptiste Nikiema ${ }^{2}$ and Sodiomon Bienvenue Sirima ${ }^{1}$ \\ ${ }^{1}$ Centre National de Recherche et de Formation sur le Paludisme(CNRFP), 01 POB 2208 Ouagadougou 01, \\ Burkina Faso. \\ ${ }^{2}$ Laboratoire de pharmacognosie et phytothérapie, Unité de Formation et de Recherche en Sciences de la Santé, \\ Université de Ouagadougou, 03 BP7021 Ouagadougou 03, Burkina Faso.
}

Received 15 November, 2016; Accepted 19 December, 2016

\begin{abstract}
Research and development of new antiplasmodial molecules in plant is a very important way for the development of new anti-malarial drugs. In this study, Vernonia cinerea Less (Asteraceae) was selected for its promising antiplasmodial activity because it is traditionally used in Burkina Faso to treat malaria. The aim of this study was to investigate the antiplasmodial activity of this whole plant. Five crude extracts of $V$. cinerea Less were prepared from the solvents of increasing polarity $\left(\mathrm{CH}_{2} \mathrm{Cl}_{2}, \mathrm{CH}_{3} \mathrm{OH}\right.$, $\mathrm{CH}_{3} \mathrm{OH} / \mathrm{H}_{2} \mathrm{O}$ (1/1), $\mathrm{H}_{2} \mathrm{O}$ and alkaloids extracts). The method of Ciulei (1982) and thin layer chromatography were used for chemical characterization. The p-LDH technique was used in vitro. Extracts were evaluated in vitro for efficacy against the Plasmodium falciparum strain K1, which is resistant to chloroquine, and 3D7, which is sensitive to chloroquine. The crude extracts of alkaloids showed the $\mathrm{IC}_{50}=4.25 \mu \mathrm{g} / \mathrm{ml}$ with the strains $3 \mathrm{D} 7$ and $\mathrm{IC}_{50}=2.56 \mu \mathrm{g} / \mathrm{ml}$ with the $\mathrm{K} 1$ strains. The $\mathrm{CH}_{2} \mathrm{Cl}_{2}$ extracts showed the $\mathrm{IC}_{50}=8.42 \mu \mathrm{g} / \mathrm{ml}$ and $\mathrm{IC}_{50}=5.85 \mu \mathrm{g} / \mathrm{ml}$ on strains $3 \mathrm{D} 7$ and $\mathrm{K} 1$, respectively. The $\mathrm{CH}_{3} \mathrm{OH}$ extracts showed the $\mathrm{IC}_{50}=21.08 \mu \mathrm{g} / \mathrm{ml}, \mathrm{CH}_{3} \mathrm{OH} / \mathrm{H}_{2} \mathrm{O}$ extracts gave $41.56 \mu \mathrm{g} / \mathrm{ml}$ and $\mathrm{H}_{2} \mathrm{O}$ extracts gave $37.17 \mu \mathrm{g} / \mathrm{ml}$ on strains of $P$. falciparum $\mathrm{K} 1$. The present study highlighted the very promising antiplasmodial activity of $V$. cinerea Less. The most antiplasmodial activity of this plant extracts merit further study about its in vivo antiplasmodial activity in Plasmodium berghei infected mice.
\end{abstract}

Key words: Vernonia cinerea Less, alkaloids, triterpenes, antiplasmodial activity, Plasmodium falciparum.

\section{INTRODUCTION}

Malaria is a potential fatal parasitic disease that remains a public health concern in tropical countries, thus also in Burkina Faso. Globally, 198 million cases of malaria are registered per year, causing about 438000 deaths
(WHO, 2015). The burden is particularly heavy in Africa where $90 \%$ of all fatal cases occur, of which $78 \%$ occurs in children under the age of five (WHO, 2014). Efforts for malaria eradication have been made from 2000 to 2013

*Corresponding author. E-mail: somaaboubakar@yahoo.fr Tel: (+226) 20970102 , (+226) 76129189. Fax: (+226) 20 97 04 57.

Author(s) agree that this article remain permanently open access under the terms of the Creative Commons Attribution License 4.0 International License 
(WHO, 2014), but this is hampered by the resistance of Plasmodium falciparum to antimalarial drugs available (Dondorp et al., 2012). The history of malaria has shown that plants are a source of new molecules. This is the case of quinine that has been isolated from Chincona and artemisinin that has been isolated from Artemisia annua (Batista et al., 2009; Bero and Joëlle, 2011; Bero et al., 2009; Kaur et al., 2009; Nogueira and Lopes, 2011; Phillipson and Wright, 1991). Over $80 \%$ of the world's population use medicinal plants for healing (WHO, 2008, 2010). In Burkina Faso, the majority of the population use medicinal plants as the first therapeutic means (Bero et al., 2009; Traoré et al., 2009) in order to contribute to find new antimalarial molecules having a wide margin of safety and efficiency. In traditional medicine, Vernonia cinerea Less (Asteraceae) has many therapeutic uses. Its vernacular name is "little ironweed (USA)" and the whole plant is used in therapeutic. It is used to treat malaria fever, vomiting, inflammation, infections, diuresis, cancer, abortion and gastrointestinal (Jain and Puri, 1984). The decoction is used to treat cardiac pathologies, wounds, colic and diarrhea (Rivière et al., 2005). In Burkina Faso, the plant is recommended in the care of malaria and for the care of dysentery and wounds in therapeutic use. The dosage used is usually a decoction of $50 \mathrm{~g} / \mathrm{l}$ (Http://www.jardinsdumonde.org). In the face of resistance to artemisinin which is the core molecule of ACT, which extracted from $A$. annua (Asteracea), the priority is to research of new active molecules against emerging resistant strains. It was in this context that we chose $V$. cinerea Less which is a plant of the Asteracea family. The aim of the study was to evaluate the antimalarial activity of extracts from $V$. cinerea Less (Asteraceae) that is used in traditional medicine in Burkina Faso to treat malaria.

\section{MATERIALS AND METHODS}

\section{Plant collection}

The plant was collected in the Comoé region (West Burkina Faso), GPS $10^{\circ} 38^{\prime} \mathrm{N}, 4^{\circ} 45^{\prime} \mathrm{W}$ in August 2010 and authenticated by a botanist M. Madou Ouedraogo from the Comoé Regional Forestry Department. After collection, a voucher specimen of plant was deposited in the herbarium of Centre National de Recherche et de Formation sur le Paludisme (CNRFP) in Burkina Faso (Ouagadougou). Then the plant was sprayed and the raw material obtained was sent to the laboratory of pharmacognosy for preparation of crude extracts.

\section{Preparation of plant extracts}

Five (5) types of extracts were prepared from the plant powder. We obtained three organic extracts, one aqueous with water and one crude alkaloid. Crude organic extracts were prepared by maceration for $16 \mathrm{~h}$ successively with dichloromethane $\left(\mathrm{CH}_{2} \mathrm{Cl}_{2}\right)$, methanol $\left(\mathrm{CH}_{3} \mathrm{OH}\right)$ and water-methanol $\left(\mathrm{CH}_{3} \mathrm{OH} / \mathrm{H}_{2} \mathrm{O}\right)$ solvents. Plant powder $(10 \mathrm{~g})$ was used for these organic extraction methods with $100 \mathrm{ml}$ of each solvent. $\mathrm{CH}_{2} \mathrm{Cl}_{2}$ extract was air dried at room temperature. $\mathrm{CH}_{3} \mathrm{OH}$ and $\mathrm{CH}_{3} \mathrm{OH} / \mathrm{H}_{2} \mathrm{O}$ extracts were freeze-dried with lyophilisator (Brand) after total evaporation of solvents. Aqueous extracts were prepared by boiling $10 \mathrm{~g}$ of plant powder in $100 \mathrm{ml}$ of purified water for $30 \mathrm{~min}$. After cooling, solutions were filtered on cotton wool and freeze-dried. Crude alkaloid extracts were obtained by alkalization with $28 \% \mathrm{NH}_{4} \mathrm{OH}$ to $\mathrm{pH} 9$ of the plant powder and extraction with $\mathrm{CH}_{2} \mathrm{Cl}_{2}$ for $24 \mathrm{~h}$. Plant powder $(10 \mathrm{~g})$ was used by applying the classical alkaloids extraction method (Sanon et al., 2003). After $16 \mathrm{~h}$ of maceration with ammoniac and $\mathrm{CH}_{2} \mathrm{Cl}_{2}$, a percolation was made with $\mathrm{CH}_{2} \mathrm{Cl}_{2}$ solvent. Then $100 \mathrm{ml}$ of $\mathrm{CH}_{2} \mathrm{Cl}_{2}$ layer was concentrated under vacuum and then extracted with a $3 \%$ solution of $\mathrm{H}_{2} \mathrm{SO}_{4}$ to $\mathrm{pH}$. The aqueous acid solution was alkalinized again with $\mathrm{NH}_{4} \mathrm{OH}$ and extracted with $\mathrm{CH}_{2} \mathrm{Cl}_{2}$, and a crude alkaloid extracts was obtained by concentration. The yields were calculated using the following:

Extracts Yields $=\frac{\text { Mass of the crude extract obtained }}{\text { Test portion of the powder }- \text { plant }} \times 100$

\section{Characterization of chemical groups}

\section{Phytochemical screening}

For characterizing the major chemical groups, non-hydrolyzed extracts and hydrolyzed extracts were prepared. $1 \mathrm{~g}$ of each lyophilizate was weighed and mixed with $100 \mathrm{ml}$ of distilled water then decanted into a bottle to get non-hydrolyzed extracts. To obtain hydrolyzed extracts, $25 \mathrm{ml}$ of non-hydrolyzed extracts were removed and mixed with $15 \mathrm{ml}$ of $10 \% \mathrm{HCl}$, this was heated under reflux for $30 \mathrm{~min}$. After cooling, the mixture was transferred to a separating funnel. The liquid-liquid partition was done by the addition of $3 \times 10 \mathrm{ml}$ of dichloromethane. The organic phase was recovered and filtered and then stored in vials.

Phytochemical screening of plant extracts was made according to Ciulei method (1982). Chemical groups were identified by liquid medium characterization tests of the extract. Triterpenes and sterols were identified with Liebermann-Büchard test. Tannins presence has been highlighted by the reaction of $\mathrm{FeCl}_{3} 1 \%$ test tubes. Saponins were identified with the observation of persistent foam column. Coumarins were detected with $\mathrm{NH}_{4} \mathrm{OH} 10 \%$, UV (366 $\mathrm{nm})$. Emodols and anthracenosids were identified with the Bornträger test. Carotenoids were detected with the $\mathrm{H}_{2} \mathrm{SO}_{4}$.

\section{Chromatographic analysis thin layer (TLC)}

Five microliters of each of the dichloromethane extracts, nonhydrolyzed extracts and hydrolyzed extracts were deposited on chromatography plates (silica gel G60, Merck). The plates were dried in ambient air and placed in migration vats covered before hand containing appropriate solvent systems. The distance covered of the eluent (solvent front) is predefined at $8 \mathrm{~cm}$ from the extracts of the deposition line. At the end of migration, the plates were removed and oven dried, and then the UV (254 or $366 \mathrm{~nm}$ ) was read and after visualized with a reagent specific to the desired chemical groups. Alkaloids were identified with migration solvent toluene-ethyl acetate-diethylamine (17.5: 5: 2.5) and revealed with Draggendorf test. Triterpenes and sterols were identified with migration solvent $\mathrm{n}$-hexane-ethyl acetate-toluene (6: 2: 4) and revealed with sulfuric acid $3 \%$ in ethanol.

Tannins has been highlighted by the solvent migration ethyl acetate-methanol-water (2: 1: 1) and revealed with aqueous solution of ferric chloride to $1 \%$. Coumarins, emodols and anthracenosids were detected with migration solvent n-hexane- 
ethyl acetate-toluene to 6: 2: 2 and revealed with the $\mathrm{KOH}$ solution $(1 \mathrm{~N})$.

\section{Strains of $P$. falciparum}

The biological material used was strains of $P$. falciparum, the species responsible for the majority of malaria cases in Africa. Strains of $P$. falciparum resistant to chloroquine $\mathrm{K} 1$ and sensitive to chloroquine 3D7 were used. The K1 parasites were provided by the laboratory Warhust, London School of Hygiene and Tropical Medicine, London, England, United Kingdom (LSHTM). The 3D7 parasites were provided by the Laboratory Nuguchi Memorial Institute on Medical Research (NMIMR) (Ghana). They were maintained in continuous culture in human blood in the Laboratory of "Centre National de Recherche et de Formation sur le Paludisme" (CNRFP) in Burkina Faso (Ouagadougou).

\section{Continuous culture of parasites in vitro by the method of Trager}

The strains in continuous culture were maintained using the technique of Trager and Jensen (1976) and we renewed the culture medium every $24 \mathrm{~h}$. Parasites were thawed and cultured in flasks containing complete culture medium composed of RPMI 1640, Lglutamine $2 \%$, Stamps Hepes $2 \%$, Gentamicin 0.5\%, Albumax $5 \%$ and Hypoxanthine $0.5 \%$. The flasks containing the culture were aerated with mixed gas composed of $2 \% \mathrm{O}_{2}, 5 \% \mathrm{CO}_{2}$, and $93 \% \mathrm{~N}_{2}$. The flasks were then incubated in the $\mathrm{CO}_{2}$ incubator at $37^{\circ} \mathrm{C}$ under conditions for maximal growth. Parasitaemia was controlled by making blood smears after the renewal of the culture medium. When parasitaemia reached $6 \%$, a subculture was made using fresh blood without the interference from blood group $A+$.

\section{In vitro evaluation of antiplasmodial activity}

The antiplasmodial activity of extract from $V$. cinerea Less was evaluated using the technique of Plasmodium Lactate Deshydrogenase (pLDH). Reference products (Dihydroartemisinin and Chloroquine) and extracts were dissolved in dimethylsulfoxide (DMSO) or in distilled water. The starting concentration of the extracts was $10 \mathrm{mg} / \mathrm{ml}$ that was further diluted to reach a final concentration of $100 \mu \mathrm{g} / \mathrm{ml}$. The tests were performed on 96-well plates filled with a fixed volume of parasitized erythrocytes $(2 \%$ parasitaemia). Samples were serially diluted with complete culture media (RPMI 1640 with albumax) to achieve the required concentration with DMSO concentration $<0.5 \%$. Each extract was applied in a series of duplicate dilutions (final concentrations ranging from 0.78 to $50 \mu \mathrm{g} / \mathrm{ml}$ ) on two rows. Dihydroartemisinin was used to validate the malaria test and chloroquine diphosphate salt (Sigma Aldrich) was used to validate the real chloroquine resistance of malaria strain $\mathrm{K} 1$. Infected and uninfected erythrocytes $\mathrm{A}+$ were used as positive and negative controls, respectively.

After $72 \mathrm{~h}$ of incubation, the plates' counterpart's tests plates were prepared and the various substrates and coenzyme were then added. $100 \mu \mathrm{l}$ MALSTAT (160 ml distilled $\mathrm{H}_{2} \mathrm{O}, 200 \mu \mathrm{l}$ Triton X100, $2 \mathrm{~g}$ of L-Lactate, $0.66 \mathrm{~g}$ Trizma base, $66 \mathrm{mg}$ 3-acétylpiridine adenine di-nucleotide (APAD), at $\mathrm{pH}$ 9), $25 \mu \mathrm{l}$ NBT/PES $(100 \mathrm{ml}$ of distilled water, $160 \mathrm{mg}$ of NTB and PES $8 \mathrm{mg}$ ) and $20 \mu \mathrm{l}$ of blood from the test plate was dispensed in each well including positive and negative controls. After $10 \mathrm{~min}$ of incubation, the plates were read on a spectrophotometer at a wavelength of $650 \mathrm{~nm}$. Data were scored and analyzed using Microsoft Excel 2007. The mean optical density of negative controls was subtracted from that of each product to obtain the percentage of viability.
$\%$ viability $=\frac{\text { OD product }- \text { OD negative control }}{\text { OD positive control }} \times 100$

The $50 \%$ inhibitory concentrations $\left(\mathrm{IC}_{50}\right)$ were calculated graphically with the Table Curve 2D v.5.0 software using the percentages of viability or cells proliferation versus log concentration. The $\mathrm{IC}_{50}$ of various extracts obtained were analyzed according to the criteria Deharo (Deharo et al., 2001); good activity $\mathrm{IC}_{50}<=5 \mu \mathrm{g} / \mathrm{ml}$, moderate activity $5<\mid \mathrm{C}_{50} \leq 10 \mu \mathrm{g} / \mathrm{ml}$, and inactive $\mathrm{IC}_{50}>10 \mu \mathrm{g} / \mathrm{ml}$.

\section{RESULTS AND DISCUSSION}

Five types of extracts were prepared. Phytochemical screening of $V$. cinerea Less revealed the presence of alkaloids, triterpenes and sterols, saponins, tannins, emodols, anthracenosids, coumarins, and carotenoids (Tables 1 and 2). The in vitro antiplasmodial activity of the crude extracts on strains reference $\mathrm{K} 1$ and 3D7 was assessed by using five crude extracts of plant prepared. Amongst the 5 extracts tested, alkaloids extracts were identified as having good antimalarial effects $\left(\mathrm{IC}_{50}<5\right.$ $\mu \mathrm{g} / \mathrm{ml}), \mathrm{CH}_{2} \mathrm{Cl}_{2}$ with moderate effects $\left(5 \mu \mathrm{g} / \mathrm{ml} \leq \mathrm{IC}_{50}<10\right.$ $\mu \mathrm{g} / \mathrm{ml}$ ), and $\mathrm{CH}_{3} \mathrm{OH}, \mathrm{CH}_{3} \mathrm{OH} / \mathrm{H}_{2} \mathrm{O}$ and $\mathrm{H}_{2} \mathrm{O}$ as inactive $\left(\mathrm{IC}_{50} \geq 10 \mu \mathrm{g} / \mathrm{ml}\right.$ ) (Table 3 ) according to Deharo et al. (2001). The best antimalarial effects were obtained with alkaloids extracts of plant (Figures 1 and 3 ).

The crude alkaloids extracts from the whole plant showed good antimalarial effects against the chloroquineresistant strain $\mathrm{K} 1$, with $\mathrm{IC}_{50}$ values $2.56 \mu \mathrm{g} / \mathrm{ml}$. The moderate antimalarial effects were obtained with dichloromethane extracts against $\mathrm{K} 1$, with $\mathrm{IC}_{50}$ values $5.85 \mu \mathrm{g} / \mathrm{ml}$ (Figures 2 and 4).

In Cambodia, a similar study showed that dichloromethane extracts of $V$. cinerea had an $\mathrm{IC}_{50}=18.3$ $\mu \mathrm{g} / \mathrm{ml}$ with the W2 malaria strain chloroquine-resistant (Hout et al., 2006). Although, our results are different from those of Simonsen et al. (2001) in India on ethanol extracts $(82 \mu \mathrm{g} / \mathrm{ml})$ tested on 3D7.

Based on Deharo's efficiency criteria, results from Cambodia and India are the same as our findings. These differences may be related to many parameters, including the local environment and the collection periods, which contribute to the variation of the chemical components of the plant as shown in a previous study on seasonal effects on bioactive compounds (Aires et al., 2011).

In Burkina Faso, a previous study showed that alkaloids extracts of bark of Terminalia avicennoides had an $\mathrm{IC}_{50}=2.9 \mu \mathrm{g} / \mathrm{ml}$ with the $\mathrm{K} 1$ malaria strain (Sanon et al., 2013). Based on Deharo's efficiency criteria, results from this plant are a same from our findings.

The previous study was conducted with Dicotoma tomentosa (Asteracea) also collected in Burkina Faso, and in a different area. The antiplasmodial activity obtained with this plant $\left(\mathrm{IC}_{50}=1.9 \pm 0.2 \mu \mathrm{g} / \mathrm{ml}\right)$ was different from our dichloromethane extracts based on Deharo's efficiency criteria (Jansen et al., 2012).

In summary, our study confirms the pharmacological 
Table 1. Summary of phytochemical screening of plant extracts was made according to Ciulei method (1982).

\begin{tabular}{lccccccc}
\hline \multirow{2}{*}{ Chemical groups } & \multicolumn{3}{c}{ Hydrolyzed extracts } & \multicolumn{3}{c}{ Crude non-hydrolyzed extracts } \\
\cline { 2 - 8 } & $\mathrm{CH}_{3} \mathrm{OH}$ & $\mathrm{CH}_{3} \mathrm{OH} / \mathrm{H}_{2} \mathrm{O}$ & $\mathrm{H}_{2} \mathrm{O}$ & $\mathrm{CH}_{3} \mathrm{OH}$ & $\mathrm{CH}_{3} \mathrm{OH} / \mathrm{H}_{2} \mathrm{O}$ & $\mathrm{H}_{2} \mathrm{O}$ & $\mathrm{CH}_{2} \mathrm{Cl}_{2}$ \\
\hline Alkaloids & $\mathrm{nr}$ & $\mathrm{nr}$ & $\mathrm{nr}$ & - & - & - & - \\
Saponosids & $\mathrm{nr}$ & $\mathrm{nr}$ & $\mathrm{nr}$ & + & + & + & $\mathrm{nr}$ \\
Flavonoids & - & - & - & $\mathrm{nr}$ & $\mathrm{nr}$ & $\mathrm{nr}$ & - \\
Triterpenes/Sterols & + & + & + & $\mathrm{nr}$ & $\mathrm{nr}$ & $\mathrm{nr}$ & + \\
Tannins & $\mathrm{nr}$ & $\mathrm{nr}$ & $\mathrm{nr}$ & + & + & + & $\mathrm{nr}$ \\
Anthracenosids & + & - & - & $\mathrm{nr}$ & $\mathrm{nr}$ & $\mathrm{nr}$ & $\mathrm{nr}$ \\
Anthocyanosids & - & - & - & $\mathrm{nr}$ & $\mathrm{nr}$ & $\mathrm{nr}$ & $\mathrm{nr}$ \\
Emodols & $\mathrm{nr}$ & $\mathrm{nr}$ & $\mathrm{nr}$ & $\mathrm{nr}$ & $\mathrm{nr}$ & $\mathrm{nr}$ & + \\
Carotenoids & $\mathrm{nr}$ & $\mathrm{nr}$ & $\mathrm{nr}$ & $\mathrm{nr}$ & $\mathrm{nr}$ & $\mathrm{nr}$ & + \\
Coumarins & + & + & - & $\mathrm{nr}$ & $\mathrm{nr}$ & $\mathrm{nr}$ & + \\
Reductors compounds & $\mathrm{nr}$ & $\mathrm{nr}$ & $\mathrm{nr}$ & - & - & - & $\mathrm{nr}$ \\
\hline
\end{tabular}

$(+)$ : Presence ; (-) : not detected; (nr): not researched

Table 2. Chemical groups showed by chromatographic analysis thin layer.

\begin{tabular}{|c|c|c|c|c|c|c|c|c|}
\hline \multirow{2}{*}{ Chemical groups } & \multicolumn{3}{|c|}{ Hydrolyzed extracts } & \multicolumn{5}{|c|}{ Crude extracts non-hydrolyzed } \\
\hline & $\mathrm{CH}_{3} \mathrm{OH}$ & $\mathrm{CH}_{3} \mathrm{OH} / \mathrm{H}_{2} \mathrm{O}$ & $\mathrm{H}_{2} \mathrm{O}$ & $\mathrm{CH}_{3} \mathrm{OH}$ & $\mathrm{CH}_{3} \mathrm{OH} / \mathrm{H}_{2} \mathrm{O}$ & $\mathrm{H}_{2} \mathrm{O}$ & $\mathrm{CH}_{2} \mathrm{Cl}_{2}$ & Alkaloids extracts \\
\hline Alkaloids & $\mathrm{nr}$ & $\mathrm{nr}$ & $\mathrm{nr}$ & $\mathrm{nr}$ & $\mathrm{nr}$ & $\mathrm{nr}$ & $\mathrm{nr}$ & + \\
\hline Tannins & $\mathrm{nr}$ & $\mathrm{nr}$ & $\mathrm{nr}$ & + & + & + & $\mathrm{nr}$ & $\mathrm{nr}$ \\
\hline Triterpenes/Sterols & + & + & + & $\mathrm{nr}$ & $\mathrm{nr}$ & $\mathrm{nr}$ & + & $\mathrm{nr}$ \\
\hline Coumarines & - & - & $\mathrm{nr}$ & $\mathrm{nr}$ & $\mathrm{nr}$ & $\mathrm{nr}$ & + & $\mathrm{nr}$ \\
\hline Emodols & $\mathrm{nr}$ & $\mathrm{nr}$ & $\mathrm{nr}$ & $\mathrm{nr}$ & $\mathrm{nr}$ & $\mathrm{nr}$ & + & $\mathrm{nr}$ \\
\hline Anthracenosids & + & $\mathrm{nr}$ & $\mathrm{nr}$ & $\mathrm{nr}$ & $\mathrm{nr}$ & $\mathrm{nr}$ & $\mathrm{nr}$ & $\mathrm{nr}$ \\
\hline Saponosids & $\mathrm{nr}$ & $\mathrm{nr}$ & $\mathrm{nr}$ & - & - & - & $\mathrm{nr}$ & $\mathrm{nr}$ \\
\hline
\end{tabular}

$(+)$ : Presence ; $(-)$ : not detected; (nr): not researched

Table 3. In vitro antiplasmodial activity of crude extracts obtained from Vernonia cinerea Less.

\begin{tabular}{|c|c|c|c|c|c|c|c|}
\hline Plant & Family & $\begin{array}{l}\text { Herbarium } \\
\text { voucher }\end{array}$ & $\begin{array}{l}\text { Part of } \\
\text { plant }\end{array}$ & Extracts & $\begin{array}{c}\text { Yield } \\
\text { (in the plant) } \\
(\%)\end{array}$ & $\begin{array}{c}\mathrm{IC}_{50} 3 \mathrm{D} 7 \\
(\mu \mathrm{g} / \mathrm{ml})\end{array}$ & $\begin{array}{l}I_{50} C_{1} \\
(\mu \mathrm{g} / \mathrm{ml})\end{array}$ \\
\hline & & & & $\mathrm{CH}_{2} \mathrm{Cl}_{2}$ & 2.57 & 8.42 & 5.85 \\
\hline Vernonia Cinerea & & & & $\mathrm{CH}_{3} \mathrm{OH}$ & 5.07 & 26.43 & 21.08 \\
\hline \multirow[t]{3}{*}{ Less } & Asteracea & Cnrfp10Vc & Whole plant & $\mathrm{CH}_{3} \mathrm{OH} / \mathrm{H}_{2} \mathrm{O}(1 / 1)$ & 7.11 & $>50$ & 41.56 \\
\hline & & & & $\mathrm{H}_{2} \mathrm{O}$ & 23.7 & $>50$ & 37.17 \\
\hline & & & & Alkaloids extracts & 0.2 & 4. 25 & 2.56 \\
\hline Chloroquine & - & - & - & - & - & 0.045 & 0.126 \\
\hline Dihydro-artemisinin & - & - & - & - & - & 0.0015 & 0.002 \\
\hline
\end{tabular}

properties of this plant species shown by its antibacterial activity with petroleum ether and ethanol extracts (Somasundaram et al., 2010), antipyretic, analgesic and anti-inflammatory activity (Iwalewa et al., 2003). Another study showed a good antiplasmodial activity of vernolide C and D molecules against W2 (Chea et al., 2006). 


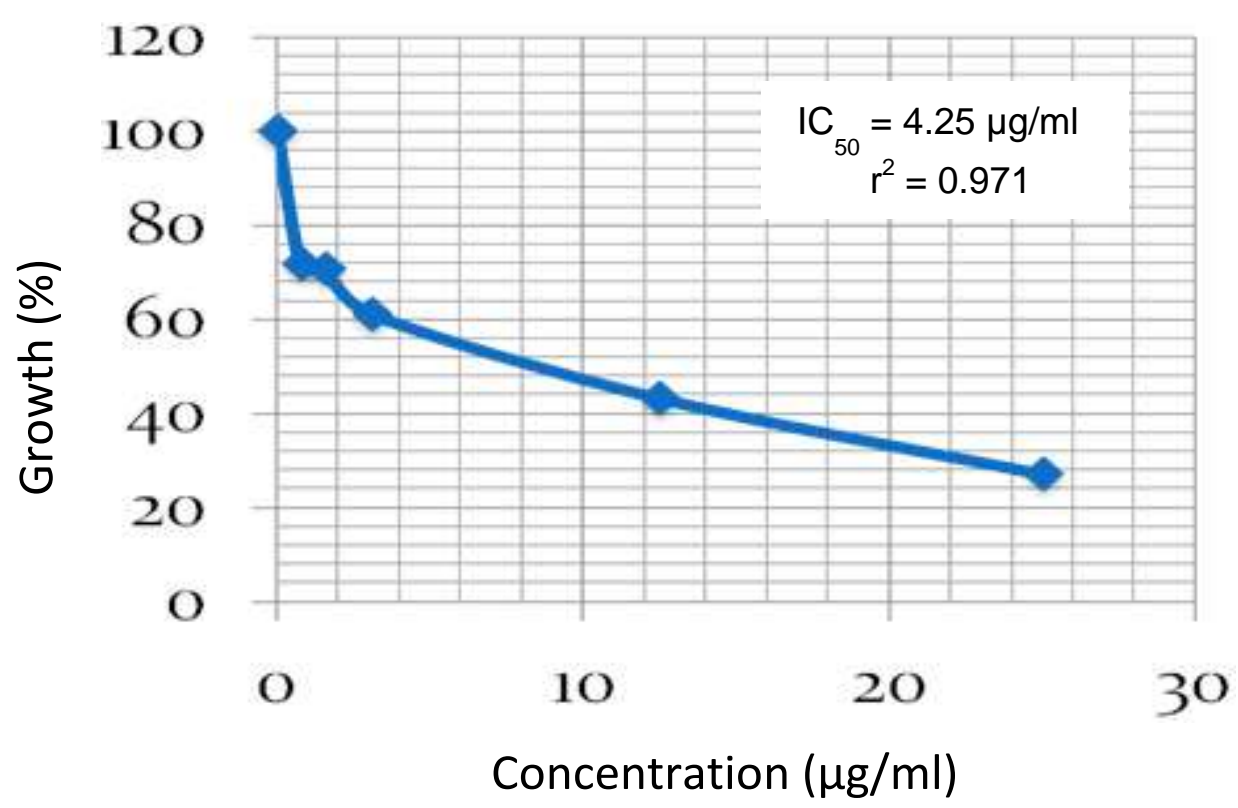

Figure 1. Curve of growth inhibition 3D7 of crude alkaloids.

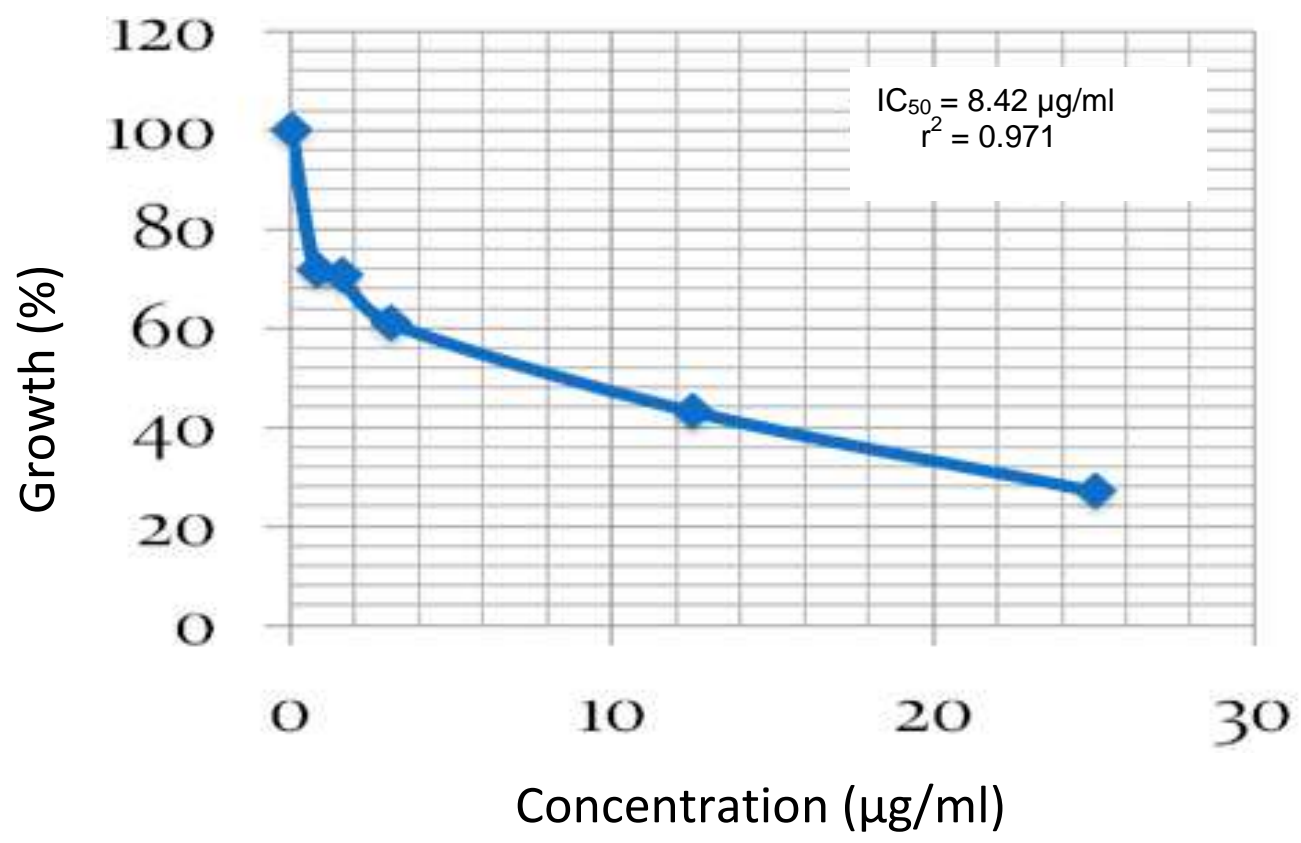

Figure 2. Curve of growth inhibition 3D7 of $\mathrm{CH}_{2} \mathrm{Cl}_{2}$ extracts.

This activity could be due to the presence of alkaloids (Bruneton, 1993) and triterpenes in the plant which mentioned by Chea et al. (2006). Alkaloids are one of the most important classes of natural products providing drugs since ancient times. The outstanding example is quinine from Cinchona succirubra (Rubiaceae) used for the treatment of malaria for more than three centuries
(Kaur et al., 2009). Several plants of the Asteraceae family have been revealed as a good source for antimalarials. The most famous one is $A$. annua, the Chinese herb from which artemisinin (qinghaosu) was isolated (Liu et al., 1992). The good activity observed from the present investigation with $V$. cinerea Less which is a member of this family, thus supports the use of this 


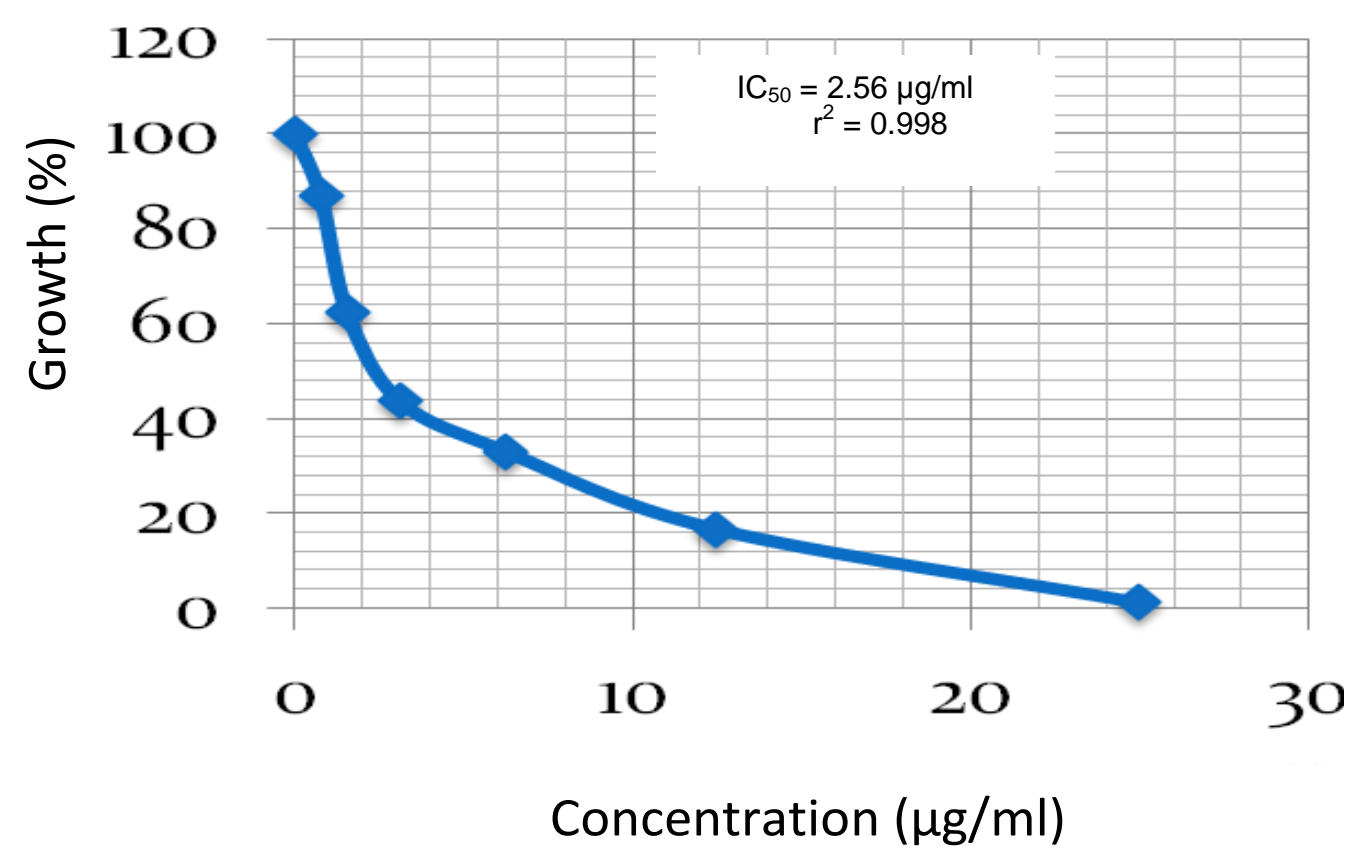

Figure 3. Curve of growth inhibition $\mathrm{K} 1$ of crude alkaloids extracts.

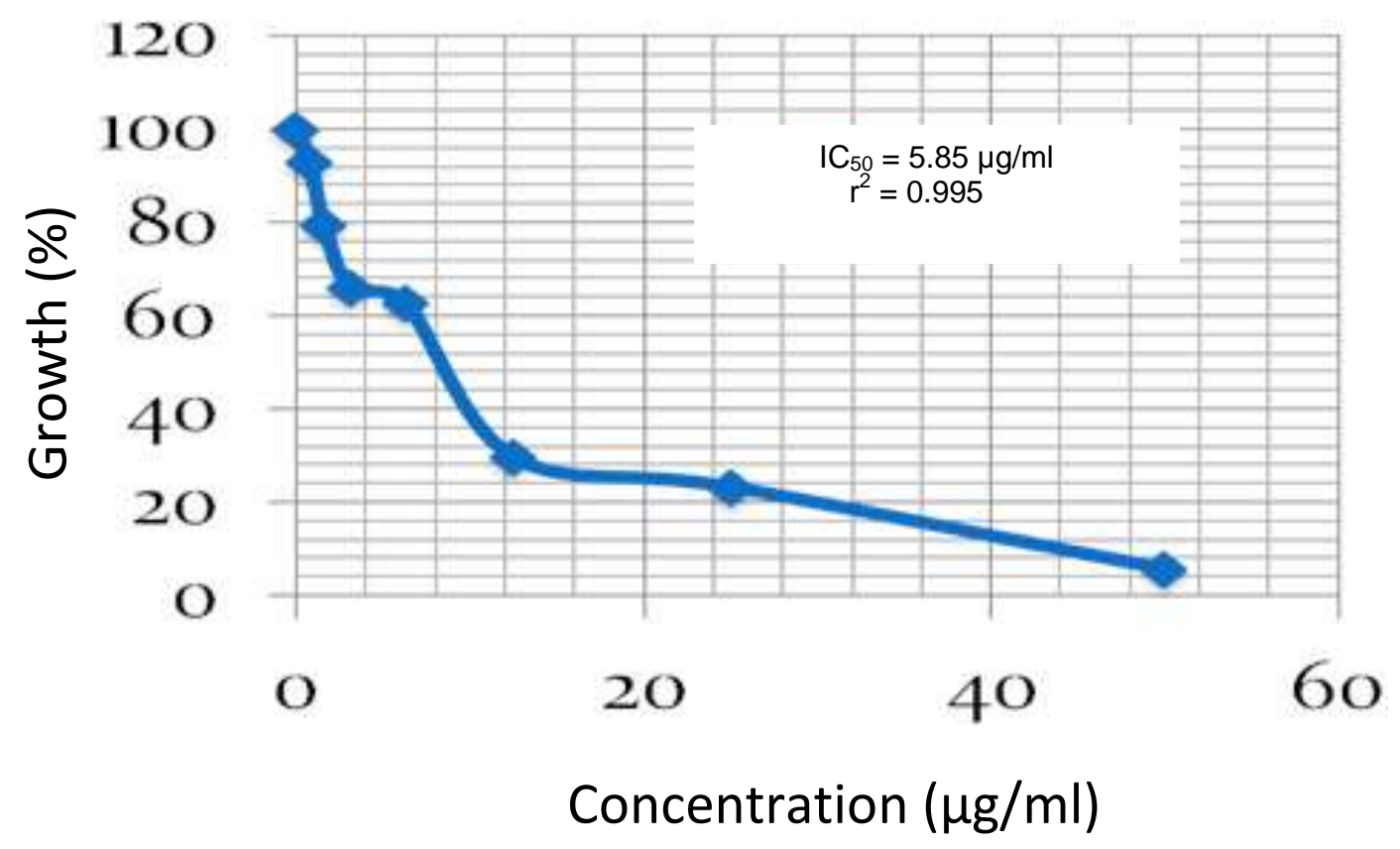

Figure 4. Curve of growth inhibition $\mathrm{K} 1$ of $\mathrm{CH}_{2} \mathrm{Cl}_{2}$ extracts.

plant for malaria in traditional medicine. This plant can be used in traditional medicine by paying close attention to the dosage. Further investigations are needed to evaluate the antiplasmodial activity in vivo in mice infected with Plasmodium berghei and to study the acute toxicity of plant extracts of $V$. cinerea Less, for the development of new drugs.

\section{CONCLUSION}

In vitro tests conducted on the parasites in the present 
study have shown that $V$. cinerea Less has a very promising antiplasmodial activity. The $\mathrm{CH}_{2} \mathrm{Cl}_{2}$ extracts and crude alkaloids allowed us to get good $\mathrm{IC}_{50}$ on plasmodial strains. These results support the traditional use of this plant in traditional medicine for the treatment of malaria. Further studies will be needed, in particular in vivo tests on mice infected with $P$. berghei to assess antiplasmodial activity.

\section{Conflict of interests}

The authors have not declared any conflict of interests.

\section{ACKNOWLEDGEMENT}

Thanks to The Centre National de Recherche et de Formation sur le Paludisme (CNRFP); The Research Institute for Health Sciences (IRSS), Department of Medicine and Traditional Pharmacopeia/Pharmacy, Ouagadougou; The Unit Training and Research in Health Science, University of Ouagadougou; Comoé Regional Forestry Department; and Centre MURAZ, Research Institute for Health. This research did not receive any specific grant from funding agencies in the public, commercial, or not for profit sectors.

\section{REFERENCES}

Aires A, Fernandes C, Carvalho R, Bennett RN, Saavedra MJ, Rosa ES (2011). Seasonal effects on bioactive compounds and antioxidant capacity of six economically important brassica vegetables. Molecules 16(8):6816-6832.

Batista R, De Jesus Silva Júnior A, De Oliveira AB (2009). Plant-derived antimalarial agents: New leads and efficient phytomedicines. part II. non-alkaloidal natural products. Molecules 14(8):3037-3072.

Bero J, Joëlle QL (2011). Natural products published in 2009 from plants traditionally used to treat malaria. Planta Med. 77:631-640.

Bero J, Michel F, Joëlle QL (2009). Antimalarial compounds isolated from plants used in traditional medicine. J. Pharm. Pharmacol. 61(11):1401-1433.

Bruneton J (1993). Pharmacognosie: phytochimie plantes médicinales (No. 581.634 B7).

Chea A, Hout S, Long C, Marcourt L, Faure R, Azas N, Elias R (2006). Antimalarial activity of sesquiterpene lactones from Vernonia cinerea. Chem. Pharm. Bull. 54(10):1437-1439.

Ciulei I (1982). Methodology for Analysis of Vegetable Drugs.Bucharest:Ministry of Chemical industry. p. 67.

Deharo E, Bourdy G, Quenevo C, Munoz V, Ruiz GS (2001). A search for natural bioactive compounds in Bolivia through a multidisciplinary approach. Part V. Evaluation of the antimalarial activity of plants used by the Tacana Indians. J. Ethnopharmacol. 77(1):91-99.

Dondorp AM, Nosten F, Yi P, Das D, Hanpithakpong W, Lee SJ, Lim P (2012). Artemisinin Resistance in Plasmodium falciparum Malaria. N. Engl. J. Med.361(5):455-467.

Hout S, Chea A, Bun SS, Elias R, Gasquet M, Timon-David P, Azas N (2006). Screening of selected indigenous plants of Cambodia for antiplasmodial activity. J. Ethnopharmacol. 107(1):12-18.

Iwalewa E, Iwalewa O, Adebayo J (2003). Analgesic, antipyretic, antiinflammatory effects of methanol, chloroform and ether extracts of Vernonia cinerea Less leaf. J. Ethnopharmacol. 86(2-3):229-234.

Jain SP, Puri HS (1984). Ethnomedicinal plants of Jaunsar-Bawar Hills, Uttar Pradesh, India. J. Ethnopharmacol. 12(213-222).
Jansen O, Tits M, Angenot L, Nicolas JP, De Mol P, Nikiema JB, Frédérich M (2012). Anti-plasmodial activity of Dicoma tomentosa (Asteraceae) and identification of urospermal A-15- O-acetate as the main active compound. Malar. J. 11(1), 289.

Kaur K, Jain M, Kaur T, Jain R (2009). Antimalarials from nature. Bioorg. Med. Chem. 17(9):3229-3256.

Liu KCSC, Yang SL, Roberts MF, Elford BC, Phillipson JD (1992). Antimalarial activity of Artemisia annua flavonoids from whole plants and cell cultures. Plant Cell Rep. 11(12):637-640.

Nogueira CR, Lopes LMX (2011). Antiplasmodial natural products. Molecules 16(3):2146-2190.

Phillipson JD, Wright CW (1991). Can ethnopharmacology contribute to the development of antimalarial agents? J. Ethnopharmacol. 32(13):155-165.

Rivière C, Nicolas JP, Caradec ML, Désiré O, Schmitt A (2005). Les plantes médicinales de la région nord de madagascar: une approche ethnopharmacologique. Ethnopharmacologia (36):36-48.

Sanon S, Gansane A, Ouattara LP, Traore A, Ouedraogo IN, Tiono A,Sirima SB (2013). In vitro antiplasmodial and cytotoxic properties of some medicinal plants from western Burkina Faso. Afr. J. Lab. Med. 2(1):1-7.

Sanon S, Ollivier E, Azas N, Mahiou V, Gasquet M, Ouattara CT, Fumoux $F$ (2003). Ethnobotanical survey and in vitro antiplasmodial activity of plants used in traditional medicine in Burkina Faso. J. Ethnopharmacol. 86(2-3):143-147.

Simonsen HT, Nordskjold JB, Smitt UW, Nyman U, Palpu P, Joshi P, Varughese $G$ (2001). In vitro screening of Indian medicinal plants for antiplasmodial activity. J. Ethnopharmacol. 74(2):195-204.

Somasundaram A, Velmurugan V, Senthilkumar GP (2010). In vitro Antimicrobial Activity of Vernonia Cinerea (L) Less. Pharmacologyonline-Newsletter 2: 957-960.

Trager W, Jensen JB (1976). Human malaria parasites in continuous culture. Science 193(4254):673-675.

Traoré A, Derme Al, Sanon S, Gansane A, OuattaraY, Nebié I, Sirima SB (2009). Connaissances ethnobotaniques et pratiques phytothérapeutiques des tradipraticiens de santé de la Comoé pour le traitement du paludisme: processus d'une recherche scientifique de nouveaux antipaludiques au Burkina Faso. Ethnopharmacologia 43:35-46.

World Health Organization (WHO) (2008). World Malaria Report. Press, Geneva.

World Health Organization (WHO) (2010). Guidelines for registration of traditional medicines in the WHO African region.

World Health Organization (WHO) (2014). World Malaria Report. Geneva.

World Health Organization (WHO) (2015). World Malaria Report 2015. 